Daina Ose, Dr. iur.

Latvijas Universitātes Juridiskā fakultāte, Latvija

\title{
ATKĀPES NO SACĪKSTES PRINCIPA CIVILPROCESĀ
}

\section{DEROGATION FROM ADVERSARIAL PRINCIPLE IN CIVIL PROCEEDINGS}

\begin{abstract}
Summary
Providing for competition in civil proceedings is one of the elements pertaining to fair court. Judge, as a guide of litigation process, bears a duty to evaluate and, within the boundaries of a certain proceedings, give instructions to the participating parties. The task of court is to scrutinize all the circumstances of the case, determining the composition of the facts to be proved. The initiative of the court is limited to providing instructions regarding necessity to supply the evidence to what was indicated by parties themselves, but court has no right to demand a certain type of evidence or a certain type of means of proof.
\end{abstract}

Atslēgvārdi: sacīkstes princips, pierādījumi, pierādīšana

Keywords: adversarial principle, evidence, proof

Civiltiesiskā strīda pušu sacīkste civillietā un tiesneša iniciatīva tiesvedībā ir divi savstarpēji ietekmējoši elementi, kas nodrošina katras lietas vispusīgu un pilnīgu apstākḷı noskaidrošanu un strīda izskatī̌šnu tiesā. Dažādos laika posmos likumdevējs, kā arī tiesu prakse ir visai atškł̧irīgi veidojusi prioritātes starp šiem norādītajiem un tiesvedībā būtiskajiem elementiem, mēginādama atrast pēc iespējas optimālu lĩdzsvaru taisnīga rezultāta sasniegšanai. Civilprocesa likumāa ${ }^{-1}$ pètot pēdējo piecu gadu laikā veiktos grozījumus, ir vērojama tendence stiprināt tiesneša iniciatīvu, bet vienlaikus tiek akcentētas arī pušu tiesības sacìkstes principa ietvaros. Tādējādi šì raksta mērkis ir noskaidrot civilprocesa kā tiesību jomas pašreizējās prioritātes sacìkstes principa un tiesneša iniciatīvas savstarpējai mijiedarbībai. Pētijjuma pamatā tiek analizēti Civilprocesa likuma grozijumi, tiesu prakse un tiesību zinātnieku un juristu publicētie viedokḷi.

Sacikstes nodrošināšana civilprocesā ir viens no taisnīgas tiesas elementiem. To vairākkārt ir atzinusi Satversmes tiesa, uzsverot, ka "taisnīga tiesa kā pienācīgs, tiesiskai valstij atbilstošs tiesas process aptver vairākus elementus - savstarpēji saistītas tiesības. Tajā ietilpst, piemēram, tiesības uz pieeju tiesai, pušu līdztiesības un sacīkstes princips, tiesības tikt uzklausitam, tiesỉbas uz motivētu tiesas spriedumu, tiesibas uz pārsūdzību." Tādējādi, lai nodrošinātu tiesības uz taisnīgu tiesu, pušu sacìkstes realizēšana notiek, ņemot vērā arī citus procesuālos principus, kas cieši saistīti ar sacìkstes principu. Sacikstes princips nekādā gadījumā nav skatāms atrauti no citiem principiem

Civilprocesa likums: LV Likums. Latvijas Vēstnesis, 1998. 3. novembris, Nr. 326/330.

2 Satversmes tiesas 2008. gada 5. novembra sprieduma lietā Nr. 2008-04-01, 8.2. punkts, Latvijas Vēstnesis, 2008. 11. novembris, Nr. 175 (3959) un 2010. gada 17. maija sprieduma lietā Nr. 2009-93-01, 8.3. punkts., Latvijas Vēstnesis, 2010. 20. maijs, Nr. 79 (4271). 
vai arī nav stādāms augstāk par citiem civilprocesa principiem. Juridiskajā literatūrā ir atzīts: "Sacīkstes principa ievērošana ir būtiska visā lietas izskatīšanas gaitā, tomēr nedrīkstētu neņemt vērā to, ka tas ir tikai viens no principiem, kas ievērojams, izskatot lietu. Un vēl būtiski ir ievērot to, ka sacīkstes princips ir vienā līmenī ar citiem tiesību principiem, kuri tiek izmantoti procesā.”’ Šādai atziṇai var piekrist, jo pušu sacìkste tiek veikta, ievērojot tādus principus kā dispozitivitāti, līdztiesību un godprātīgu tiesību un pienākumu izmantošanu, kā arī n,emot vērā citus nozīmīgus procesa principus. Pušu sacikste pati par sevi bez sasaistes ar citiem tiesvedibas principiem var novest pie pušu patvaḷas un pretējās strīda puses tiesību un interešu aizskaršanas. Tādējādi tieši tiesnesim kā tiesvedības procesa virzītājam ir uzlikts pienākums vērtēt un attiecīgajā procesā piel̦autajās robežās dot norādes lietas dalībniekiem un pieṇemt lēmumus, lai pēc iespējas ātrāk un kvalitatīvāk nonāktu līdz taisnīgam strīda risinājumam. Jau starpkaru periodā tiesību zinātnieks Vladimirs Bukovskis ir norādījis, ka jautājumā par patiesības noskaidrošanu tiesa nekādā ziņā nav vienaldzīga skatītāja, kas pasīvi uztver tikai to, ko puses ceḷ tai priekšā. Lai gan pierādijjumus iesniedz vai uz tiem atsaucas katra puse, tiesai tomēr jāraugās uz tiem kritiski, jānoskaidro to objektīvā vērtība un jācenšas noskaidrot patiesos faktiskos lietas apstākḷus, kam gala rezultātā jānoved pie patiesības. ${ }^{4}$ Šādā veidā tiesneša iniciatīva saskaras ar pušu sacīksti.

Sacīkstes principa aktualitāte civilprocesā ir nemainīga kategorija, kura pastāvīgi rada diskusijas gan tiesību zinātnieku vidū, gan arī jaunas atziņas tiesu praksē, mēginot interpretēt šì principa būtību un noteikt tā saturu atkarībā no tā, kādā apmērā vienā vai otrā laika periodā dominē pušu sacīkste pār tiesneša iniciatīvu. Sacìkstes princips tiek saprasts kā viens no būtiskākajiem civilprocesa vispārīgajiem principiem, kurš noteic, ka tiesa izskata civiltiesisko strīdu, pamatojoties uz pierādījumiem, ko iesniedz puses. Šis princips normatīvi ir nostiprināts likuma "Par tiesu varu" 525 . pantā, kas ḷauj prezumēt, ka tas ir attiecināms uz jebkuru tiesvedības procesu. Tomēr likumdevējs ir taisījis atrunu un norādījis, ka sacīkstes realizācija nepastāv administratīvajā tiesvedībā, kurā kā dominējošais tiek akcentēts objektīvas izmeklēšanas princips ${ }^{6}$. Saistībā ar šo principu noregulējums ir ietverts Administratīvā procesa likuma ${ }^{7} 107$. panta ceturtajā daḷā. Kā norādijusi Augstākā tiesa: "Tas nozīmē, ka tiesa var dot procesa dalíbniekiem norādījumus un ieteikumus pierādījumu savākšanā, kā arī var vākt pierādījumus pēc savas iniciativas. No minētās normas izriet, ka tiesa izprasa vai savāc papildu pierādỉjumus tad, ja uzskata, ka tie nepieciešami lietas apstākḷu vispusīgai noskaidrošanai." ${ }^{8}$ Savukārt sacīkstes princips ir nostiprināts Civilprocesa likuma 10. pantā, kurš noteic, ka sacìkste notiek, pusēm dodot paskaidrojumus, iesniedzot pierādījumus, tiesai adresētus pieteikumus, piedaloties liecinieku un ekspertu nopratināšanā, citu pierādījumu pārbaudē

3 Krūmiņš M. Pierādījumu apjoms prasības pamatošanai - prasītāja kompetence. Jurista Vārds, 31.01.2017., Nr. 5 (959), 21.-24. lpp.

4 Bukovskis V. Civīlprocesa mācības grāmata. Rìga: Bukovskis, 1933, 332.-333. lpp.

5 Par tiesu varu: LV Likums. Latvijas Vēstnesis, Latvijas Republikas Augstākās Padomes un Valdības Ziņotājs, 1993. 14. janvāris, Nr.1/2.

6 Neimanis J. Objektīiās izmeklēšanas princips. Jurista Vārds, 21.04.2015., Nr. 16 (868), 10.-16. lpp.

7 Administratīvā procesa likums: LV Likums. Latvijas Vēstnesis, 2001. 14. novembris, Nr. 164.

8 Latvijas Republikas Augstākās tiesas Administratīvo lietu departamenta 2018. gada 9. aprīḷa Rīcības sēdes lēmums lietā Nr. A420126016, SKA-772/2018. 
un novērtēšanā, piedaloties tiesu debatēs un veicot citas procesuālās darbības. Uzskaitīto darbību apjoms sacīkstes realizēšanā civilprocesā nav aprobežots tikai ar pierādījumu iegūšanu un iesniegšanu lietā, bet tā izpausme ir cieši saistīta arī ar procesuālo lìdzekḷu un veicamo darbību izvēli. Lìdz ar to sacīkstes princips civilprocesā ir cieši saistīts ar dispozitivitātes principu, ${ }^{9}$ kuru saprot kā pušu brīvu rīcību ar savām subjektīvajām tiesībām un to aizsardzības procesuālajiem līdzekḷiem. ${ }^{10}$ Tas nozīmē to, ka civilprocesā uzsvars tiek likts uz pašu pušu aktīvu rīcību un zināšanām par nepieciešamo pierādījumu iegūšanu un pierādāmiem apstākḷiem lietā. Tiesneša kā procesa vadītāja iniciatīva pierādījumu vākšanā ir ierobežota, piel̦aujot pierādijjumu izprasǐšanu tikai pēc pušu lūguma un tikai gadījumā, ja attiecīgā puse objektīvu iemeslu dēl pati šo pierādijumu iegūt nevar. Šāds ierobežojums tiesnesim ir noteikts ar Civilprocesa likuma 112. panta pirmo dalı un ir pastiprināts ar tiesu prakses atziṇu - ja prasītājs ir pieteicis tiesai motivētu lūgumu par rakstveida pierādījumu izprasīšanu, kurus viṇam pašam nav iespējams iesniegt tiesā, tiesai ir pienākums tos izprasīt. ${ }^{11}$ Tomēr uz tiesneša aktīvo lomu lietas izskatǐšanā, pastāvot pušu sacīkstei, norāda cita tiesu prakses atziṇa, kura skaidro, ka "izskatot lietu, tiesai jānoskaidro lietas apstāḳli, kuri ietilpst pierādī̌sanas priekšmetā - prasības pamata fakti un atbildētāja iebildumu pamata fakti (meklējamie fakti). Meklējamos faktus norāda puses, bet faktu sastāvu, kas jāpierāda lietā, galīgi nosaka tiesa saskaņā ar tām materiālo tiesību normām, kuru hipotēzēs ir norādīti fakti, kas nosaka pušu apstrīdētās un aizskartās tiesības un tām atbilstošus pienākumus." 12 Tādējādi var secināt, ka gan civilprocesā, gan administratīvajā procesā tiesas uzdevums ir lietas apstākḷu vispusīga noskaidrošana, nosakot pierādāmo faktu sastāvu. Turklāt sacīkste ir vairāk vērsta uz pušu brīvu rīcību pierādīšanas līdzekḷu un pierādījumu izvēlē, bet nevis uz pierādījumu iesniegšanu kā procesuālu darbību (pierādījumu nasta). Pierādījumu iesniegšanas pienākums lietas dalībniekam ir noteikts arī administratīvajā procesā, kurā, kā tas tika iepriekš norādīts, pušu sacīkstes vietā darbojas objektīvas izmeklēšanas princips un pierādỉjumu iegūšanā tieši tiesnesim ir aktīva loma. Administratīvo tiesu judikatūrā ir nostiprinājusies atziņa, ka privātpersonas pienākums nodrošināt nepieciešamos pierādījumus palielinās proporcionāli tam, cik l,oti lēmuma pieṇemšanas process notiek pašas privātpersonas interesēs. Attiecībā uz faktiem, kas veicina privātpersonai labvēlīga lēmuma pieņemšanu, ir dabiski un atbilstoši pierādījumu nastu uzlikt privātpersonai, nevis valsts pārvaldei. ${ }^{13}$ Tiesnesis šajā gadījumā sniedz norādes par nepieciešamajiem pierādijjumiem un raisa diskusiju par apstākḷu noskaidrošanu ${ }^{14}$, bet pierādījumus iesniedz lietas dalībnieks tiktāl, ciktāl šie

Līcis A. Prasības tiesvedībā un pierādījumi. Rīga: Tiesu namu ağentūra, 2003, 59. lpp.

10 Rozenbergs J., Brigíis I. Padomju civilprocesuālās tiesības. Rīga: Zvaigzne, 1978, 46. lpp.

11 Latvijas Republikas Augstākās tiesas Senāta Civillietu departamenta 2006. gada 5. aprīla spriedums lietā Nr. SKC-225.

12 Latvijas Republikas Augstākās tiesas Senāta Civillietu departamenta 2012. gada 21. marta spriedums lietā Nr. SKC-98/2012.

13 Sk. Latvijas Republikas Augstākās tiesas 2007. gada 4. aprīḷa sprieduma lietā Nr. SKA-93/2007 (C15075104) 14.2. apakšpunkts, 2016. gada 14. aprịla Rīcības sēdes lēmuma lietā Nr. SKA-856/2016 (A420532213) 8. punkts.

14 Karena Kellere: Vai sacikstes princips aizliedz tiesneša iesaistišanos diskusijā? Pieejams: https:// juristavards.lv/zinas/273224-iii-videolekcija-karena-kellere-vai-bsacikstes-principsb-aizliedz-tiesnesaiesaistisanos-diskusija/, sk. Jurista Vārds 20. augusts 2018. [aplūkots 2019. gada 5. maijā]. 
pierādījumi ir viṇa rīcībā vai viņam ir pieejami. Kā pamatoti ir atzìts juridiskajā literatūrā, administratīvajā procesā tiesai ir pienākums apspriest faktus ar procesa dalībniekiem, jo iespējams, ka kādi fakti tomēr nav noskaidroti pilnībā vai atšķiras procesa dalībnieku viedoklis par tiem. ${ }^{15}$ Savukārt Civilprocesa likuma (turpmāk arī CPL) 93. panta ceturtā daļa uzliek tiesai pienākumu izrādīt iniciatīvu gadījumos, kad no lietas materiāliem izriet nepieciešamība pieprasīt papildu pierādijumus, t. i., tiesai ir jāpaziņo pusēm par to, ka pierādijumi par kādu noteiktu faktu, prasijumu vai iebildumu nav iesniegti, un noteikt termiņu to iesniegšanai. Tiesneša iniciatīva aprobežojas ar norādes došanu par nepieciešamību iesniegt pierādījumus tam, uz ko ir norādijjušas pašas puses, bet tiesnesim nav tiesību norādē ietvert prasību iesniegt noteikta veida pierādījumu vai arī norādīt attiecīgu pierādīšanas līdzekli, kurā šim pierādỉjumam ir jābūt nostiprinātam. Satversmes tiesa ir atzinusi, ka minētā tiesību norma nenozìmē, ka tiesa veic objektīvo izmeklēšanu, t. i., patstāvīgi pēc savas iniciatīvas vāc patieso lietas apstākḷu noskaidrošanai nepieciešamos pierādījumus. No Civilprocesa likuma 10. panta izriet, ka katrs lietas dalībnieks ir atbildīgs par savu pienākumu pildīšanu un procesuālo tiesību pilnvērtīgu un savlaicīgu izmantošanu. ${ }^{16}$ Tādējādi izvēle iesniegt vai neiesniegt pierādījumus un kādā pierādīšanas līdzeklī tos nostiprināt, ir tikai pašas puses izvēle, kas arī raksturo sacīkstes principu. Nošķirot administratīvajā procesā raksturīgo tiesneša iniciatīvu no civilprocesā piel̦autās tiesneša iniciatīvas, juridiskajā literatūrā tiek norādīts, ka civilprocesā tiesa ir saistīta ar lietas dalībnieku iesniegtajiem faktiem un nav tiesīga norādīt lietas dalībniekiem uz citiem faktiem, kas, tiesas ieskatā, varbūt trūkst prasījuma apmierināšanai. ${ }^{17}$ Savukārt tiesu praksē ir nostiprinājusies atziņa, ka tiesneša iniciatīvas neesība saistībā ar CPL 93. panta ceturtajā daļā nostiprināto tiesneša pienākumu norādìt uz pierādījumu trūkumu, tiek vērtēts kā tāds pārkāpums, kas varēja novest pie lietas nepareizas izspriešanas. ${ }^{18}$ Šādai atziņai var piekrist vairāku apsvērumu dēḷ. Tiesas pienākums ir noskaidrot lietas apstākḷus un nonākt līdz iespējamajai patiesībai. Tikai no pušu iesniegtajiem pierādījumiem, tos vērtējot, tiesai ir iespējams noskaidrot iespējamos pagātnes notikumus un taisīt pamatotu spriedumu par strīda apstākḷiem. Turklāt tiesa var dot norādes tikai par to, ko paši lietas dalíbnieki ir norādījuši, iebilduši vai vērsuši tiesas uzmanību. Tādējādi tiesa nevar ignorēt tādu lietas dalïbnieku paskaidrojumus vai iebildumus, kuriem var būt nozīme strīda izšķiršanā, bet par kuriem nav iesniegti vai nav pietiekamā apmērā iesniegti pierādījumi lietā. Satversmes tiesa ir atzinusi, ka saskaņā ar Civilprocesa likuma noteikumiem tiesas sēde notiek, ievērojot sacīkstes principu, proti, abām pusēm ir vienlīdzīgas iespējas iesniegt dokumentus, izteikt savu viedokli tiesas sēdē, saṇemt kvalificētu juristu palīdzību. ${ }^{19} \mathrm{Lìdz}$ ar to gadijjumos, kad nepieciešams ievērot līdztiesības principu un likumības principu, tiesneša iniciatīvas ietvaros, tiesnesim ir pienākums dot norādes pusēm

15 Neimanis J., 10.-16. lpp.

16 Satversmes tiesas 2016. gada 28. septembra spriedums lietā Nr. 2016-01-01, 10.1 punkts, Latvijas Vēstnesis, 2016. 30. septembris, Nr. 190 (5762).

17 Neimanis J., 10.-16. lpp.

18 Latvijas Republikas Augstākās tiesas Civillietu departamenta 2014. gada 28. februāra spriedums lietā SKC-108/2014.

19 Satversmes tiesas 2012. gada 29. oktobra spriedums lietā Nr. 2012-05-01 16.2. punkts. Latvijas Vēstnesis, 2012.31. oktobrī, 172 (4775). 
tiktāl, ciktāl nav aizskarts sacīkstes princips. Eiropas Padomes Ministru komiteja 1984. gada 28. februāra rekomendācijā $\mathrm{Nr}$. $\mathrm{R}(84) 5^{20}$ par civilprocesa principiem tiesas spriešanas uzlabošanai atzinusi: "Tiesai vajadzētu vismaz iepriekšējās izskatī̌šnas laikā, bet, ja iespējams, visa procesa laikā uzṇemties aktīvu lomu, lai nodrošinātu strauju procesa progresu, vienlaikus ievērojot pušu tiesỉbas, tajā skaitā pušu līdztiesības principu." Vērtējot iespējamās pieḷaujamās tiesneša iniciatīvas robežas civilprocesā kopsakarā ar sacīkstes principu, likumdevējs ir pię̧āvis tiesnesim realizēt noteiktas izmeklēšanas darbības mazāk aizsargāto personu interesēs. Atsevišskās lietu kategorijās atkāpes no sacīkstes principa jau sākotnēji ir tikušas ietvertas civilprocesa likumā, paredzot tiesnesim noteiktu iniciatīvu pašam iegūt lietas izskatī̌sanai nepieciešamos pierādījumus likumā skaidri noteiktos gadỉjumos, kuri nav interpretējami paplašināti. Taču jebkuras atkāpes no sacîkstes principa ir piel̦aujamas tikai visšaurākā apmērā un tikai civilprocesa likumā noteiktajos gadijjumos un apjomā. Tādējādi tiesneša iniciatīva ir aprobežota ar nepieciešamo pierādījumu iegūšanu lietās, kas skar nepilngadīga bērna intereses (piem. CPL 238. ${ }^{1}$ panta ceturtā daḷa un 239. pants) un lietās par rīcîbspējas ierobežošanu pilngadīgai personai (piem., 266. pants, 267. pants). Šajās lietu kategorijās likumdevējs ir pieškīiris tiesai tiesības veikt izmeklēšanas darbības objektīvās patiesības noskaidrošanai tādu personu interesēs, kuras patstāvīgi pašas nespēj realizēt sacīksti un iesniegt nepieciešamos pierādījumus, kā arī veikt citas procesuāāas darbības savu interešu un tiesību aizsardzībai. Turklāt jāṇem vērā, ka nepilngadīgā bērna interešu aizsardzība kā prioritāra ir noteikta Bērnu tiesību aizsardzības likuma ${ }^{21}$ 6. panta otrajā dą̧ā, kura noteic, ka visām darbībām attiecībā uz bērnu neatkarīgi no tā, kāda institūcija tās veic, tajā skaitā arī tiesa, jābūt prioritārām bērnu tiesību un interešu aizsardzībā. Tādējādi civilprocesuālais sacìkstes princips šajā gadỉjumā tiek ierobežots ar likumu, nosakot tiesneša iniciatīvu par labu materiālajās normās nostiprinātajam bērnu tiesību aizsardzības principam. Taču vienlaikus civillietas ietvaros arī šādās lietu kategorijās, kuras skar nepilngadīgā bērna intereses, turpina darboties pušu sacīkste, t. i., kā civiltiesiskā strīda puses visbiežāk ir norādīti nepilngadīgā bērna vecāki vai aizbildņi, kuri turpina realizēt pierādīšanas nastu un citas no sacīkstes principa izrietošās procesuāāas darbības. Turklāt Civilprocesa likums, piel̦aujot tiesneša iniciatīvu, skaidri norāda, kādos tieši jautājumos tā var pastāvēt un uz kādiem noskaidrojamiem apstākḷiem to var attiecināt, t. i., tikai tādos jautājumos, kas skar bērna dzīvesvietu, bērna aprūpes kārtību, saskarsmes tiesību izmantošanas kārtību, aizliegumu bērna izvešanai no valsts. Lìdz ar to arī šajās lietu kategorijās civilprocesā paredzētās atkāpes no sacīkstes principa ir līdzsvarotas ar šì procesa ietvaros nepieciešamo nepilngadīgā bērna tiesību un interešu aizsardzību, bet tiesneša izmeklēšanas darbības nav absolūtas un ir pakārtotas tikai tādu jautājumu noskaidrošanai, uz kuriem atbildes var dot neitrāls un procesa iznākumā neieinteresēts subjekts - bārintiesa. ${ }^{22}$

Līdzīgi tiesneša iniciatīva ir ierobežota arī lietās par personas rīcībspējas ierobežošanu garīga rakstura vai citu veselïbas traucējumu dẹlı. Likumdevējs tiesai ir piešķ̄iris

20 Recommendation No. $\mathrm{R}(84)$ on the principles of civil procedure designed to improve the functioning of justice, pieejams: https://wcd.coe.int/com, [aplūkots 2019. gada 5. maijā].

21 Bērnu tiesību aizsardzības likums. LV Likums. Latvijas Vēstnesis, 1998. 8. jūlijs Nr. 199/200.

22 Bāriṇtiesu likums: LV Likums. Latvijas Vēstnesis, 2006. 7. jūlijs, Nr. 107, 4. pants. 
tiesības pašai pēc savas iniciatīvas noteikt nepieciešamo psihiatrisko vai psihologisko ekspertīzi, kā arī prasìt izziṇu no ārstniecības iestādes un citus personas rīcībspējas ierobežojuma apjoma noteikšanai nepieciešamos pierādijjumus no pieteicēja un iestādēm. Personas rīcībspējas ierobežošanas lietas tiesa skata sevišķajā tiesāšanās kārtībā un, kā norādīts Civilprocesa likuma grozỉjumu anotācijā, ${ }^{23}$ "sevišḳās tiesāšanās kārtībā nav atbildētāja un līdz ar to nerealizējas civillietu izskatīšanā noteiktais sacīkstes princips, un tāpēc tiesai ir lielāka patstāvība un iniciatīva, pieprasot un pārbaudot pierādījumus. Svarīgi, ka ekspertu un ārstu sniegtās izziṇas netiek vieglprātīgi izsniegtas, jo tās rada tālejošas sekas.” Jāatzīst, ka šādam skaidrojumam var piekrist tikai daḷēji. Atbildētāja neesamība lietā vēl nenozīmē, ka netiek realizēts sacīkstes princips. CPL 265. pantā ir ietverta prasība pieteikumam pievienot pierādījumus, kas apstiprina rīcỉbspējas ierobežošanas nepieciešamību personas interesēs, kā arī 267. pantā ir ietverta tiesība pārsūdzēt lēmumu par tiesu ekspertīzes noteikšanu. Līdz ar to var secināt, ka lietās par personas rīcībspējas ierobežošanu garīga rakstura vai citu veselības traucējumu dēḷ lietas dalībnieki sacīkstes principu var realizēt ierobežotā apjomā, t. i., izvēloties iesniedzamos pierādījumus lietā, kā arī realizējot citas procesuālās darbības, kuras ietilpst CPL 10. panta otrās daļas tvērumā. Tiesneša iniciatīva ir vērsta uz nepieciešamību objektīvi un pilnīgi izvērtēt personai nosakāmo ierobežojumu apjomu, lai aizsargātu šìs personas intereses un nenoteiktu plašākus ierobežojumus personas rīcībspējai, nekā būtu nepieciešams.

Modernizējot Civilprocesa likumu un ieviešot tajā jaunus regulējumus atseviškłu kategoriju lietās, ir izsekojama tendence ietvert tādus procesuālos elementus, kuri būtiski ierobežo lietas dalībnieku tradicionālās tiesības uz sacīkstes realizēšanu, tajā skaitā iesniegt pierādījumus lietā vai iepazìties ar jau iesniegtajiem pierādījumiem. Pie šādām lietu kategorijām ir jānorāda lietas par zaudējumu atlīdzināšanu par konkurences tiesību pārkāpumiem un lietas par komercnoslēpuma nelikumīgu iegūšanu, izmantošanu un izpaušanu.

Abos norādītajos gadījumos sacīkstes ierobežojumi tiek pamatoti ar materiālajās normās noteiktām aizsargājamām personas ${ }^{24}$ vai sabiedrības kopējām interesēm ${ }^{25}$. Nosakot jebkādus ierobežojumus pušu sacīkstei, likumdevēja uzdevums ir rūpīgi izvērtēt katras vienas puses procesuālo tiesību ierobežojuma samērīgumu ar materiālajās normās noteiktajām aizsargājamām personas tiesībām un interesēm, normatīvi noregulējot ierobežojuma apjomu un iespējamos gadījumus. Šādi procesuālie ierobežojumi var tikt attiecināmi tikai un vienīgi uz pierādījumu iegūšanu lietā nozīmīgu apstākḷu noskaidrošanai un tikai pierādī̌sanas priekšmeta un prasijjuma ietvaros.

Tas nozīmē, ka sabiedrībā notiekošie procesi pieprasa ne tikai ātras un vienkāršas procedūras, risinot subjektu privāttiesiskos strīdus, bet arī pieprasa vienlaikus ierobežot un neatklāt noteikta satura vai rakstura informāciju citiem strīda dalībniekam. Tādējādi patiesības noskaidrošanas nolūkos tiesnesis, kurš izskata lietu, ir vienīgais, kura rīcībā ir nepieciešamās ziṇas par strīda apstākḷiem. Tādēḷ šādās atseviškāà lietu

23 Grozījumi Civilprocesa likumā: LV Likums. Latvijas Vēstnesis, 2012. 14. decembris, Nr. 197. Anotācija, pieejama: http://titania.saeima.lv [aplūkots 09.05.2019.].

24 Komercnoslēpuma aizsardzības likums: LV Likums. Latvijas Vēstnesis, 2019. 14. marts, Nr. 52.

25 Konkurences likums: LV Likums. Latvijas Vēstnesis, 2001. 23. oktobris, Nr. 151. 
kategorijās vispārējās jurisdikcijas tiesnesim nepieciešams pieškirt plašākas pilnvaras pieprasìt no lietas dalībniekiem noteiktus pierādījumus, vadoties no pierādāmiem apstāklịiem. Tomēr arī šādos gadījumos ir nepieciešams Civilprocesa likumā katrā atsevišķā lietu kategorijā noteikt robežu, līdz kādai šāda tiesneša iniciatīva būtu piel̦aujama. Tādējādi izvēlēties to virzienu, ka iespējamajām atkāpēm ir jābūt izsmeļoši atrunātam tiesību normā, ierobežojot iespēju tiesneša iniciatīvu interpretēt paplašināti, attiecinot uz jebkuru vispārējās jurisdikcijas tiesā skatāmu lietu.

Tiesneša iniciatīva nav attiecināma uz likumā ietverto tiesas izvēli noteiktu procesuālo darbību veikšanai civillietas izskatī̌sanas gaitā. Tiesnesis šādā gadījumā kā procesa vadītājs izvēlas ekonomiskākos līdzekḷus, lai nonāktu līdz civiltiesiskā strīda ātrākam risinājumam, vienlaikus nodrošinot lietas dalïbnieku tiesības brīvi rīkoties ar procesuālajiem aizsardzības līdzekliem.

Juristu vidū palaikam ir vērojamas diskusijas par tiesneša iniciatīvas paplašināšanu civilprocesā un iespējamām attīstības tendencēm. Piemēram, Vācijas tiesību zinātnieki ir norādijusši, ka sacikstes princips nav nesatricināma dogma, bet gan tiesvedības interesēs ir nepieciešama tiesneša līdzdarbība patiesỉbas noskaidrošanā. ${ }^{26}$ Savukārt Francijas civilprocesā tiesneša iniciatīva ir ieguvusi stabilus piemērošanas kritērijus tiesu prakses atziṇās, nosakot sacìkstes principa piel̦aujamos ierobežojumus gan prasības tiesvedībā, gan arī seviškłajā tiesāšanās kārtībā. ${ }^{27}$ Tā kā Latvijas civilprocesā tiesneša iniciatīvas stiprināšanā un sacikstes ierobežošanā jaunu gadijjumu iekḷaušana likumā ir vērojama salīdzinoši nesen, jāatzīst, ka plašākas diskusijas par šiem jautājumiem praksē ir salīdzinoši maz. Tomēr arī šajās diskusijās tiek pausts viedoklis, ka tiesneša iniciatīva nedrīkst runāt pretim dispozitivitātes principam, it ìpaši nedrìkst ierobežot puses tiesību patstāvīgi rīkoties ar procesa gaitu, piespiest pusi lietot tādus procesuālus aizstāvēšanās līdzekḷus, kurus puse nevēlas lietot, vai arī pret puses gribu patstāvīgi lietot šos aizstāvēšanās līdzekḷus. ${ }^{28}$ Šādu robežu nospraušana ir vērā ṇemama, jo atšksiirībā no citiem procesiem civilprocesā ir nostiprināta kārtîba, kādā tiek aizsargātas privātpersonas aizskartās tiesības un ar likumu aizsargātās intereses un šo tiesỉbu un interešu aizsardzība var būt atkarīga tikai un vienīgi no personas gribas, ievērojot dispozitivitātes principu un līdztiesības principu, vienlaikus respektējot arī sacikstes principu.

\section{Kopsavilkums}

1. Nodrošinot tiesības uz taisnīgu tiesu, pušu sacīkstes realizēšana notiek, ievērojot arī citus civilprocesuālos principus. Sacìkstes princips nekādā gadījumā nav skatāms atrauti no citiem principiem vai arī nav stādāms augstāk par citiem civilprocesa principiem. Gadijumos, kad nepieciešams ievērot dispozitivitātes, līdztiesības

26 Rosenberg L., Schwab K. H. Zivilprozessrecht. München, 1993. s. 425.

27 Braudo S. Définition de Contradictoire. Pieejams: https://www.dictionnaire-juridique.com/ definition/contradictoire.php [aplūkots 09.05.2019.].

28 Laviņš A. Pārdomas par Satversmes prasībām tiesnesim. Jurista Vārds, 15.05.2018., Nr. 20 (1026), 26.-31.lpp. 
un likumības principu tiesneša iniciatīvas ietvaros, tiesnesim ir pienākums dot norādes pusēm tiktāl, ciktāl nav aizskarts sacīkstes princips.

2. Tiesnesim kā tiesvedības procesa virzìtājam ir uzlikts pienākums vērtēt un attiecìgajā procesā piel̦autajās robežās dot norādes lietas dalíbniekiem, kā arī pieņemt lēmumus, lai pēc iespējas ātrāk un kvalitatīvāk nonāktu līdz taisnīgam strīda risinājumam. Taču tiesneša iniciatīva aprobežojas ar norādes došanu par nepieciešamību iesniegt pierādījumus tam, uz ko ir norādījušas pašas puses, bet tiesai nav tiesību norādē ietvert prasību iesniegt noteikta veida pierādījumu vai arī norādìt attiecīgu pierādīšanas līdzekli, kurā šim pierādījumam ir jābūt nostiprinātam.

3. Tiesneša iniciatīva nav attiecināma uz likumā ietverto tiesneša izvēli noteiktu procesuālo darbību veikšanai civillietas izskatīšanas gaitā. Tiesnesis šādā gadījumā kā procesa vadītājs izvēlas ekonomiskākos līdzekḷus, lai nonāktu līdz civiltiesiskā strīda ātrākam risinājumam, vienlaikus nodrošinot lietas dalībnieku tiesības brīvi rīkoties ar procesuālajiem aizsardzības līdzekḷiem.

\section{BIBLIOGRĀFIJA}

\section{Literatūra}

1. Bukovskis V. Civīlprocesa mācības grāmata. Rīga: Bukovskis, 1933.

2. Krūmiņ̌̌ M. Pierādījumu apjoms prasības pamatošanai - prasītāja kompetence. Jurista Vārds, 31.01.2017., Nr. 5 (959), 21.-24. lpp.

3. Laviņš A. Pārdomas par Satversmes prasībām tiesnesim. Jurista Vārds, 15.05.2018., Nr. 20 (1026), 26.-31.lpp.

4. Līcis A. Prasības tiesvedībā un pierādījumi. Rīga: Tiesu namu aǵentūra, 2003.

5. Neimanis J. Objektīvās izmeklēšanas princips. Jurista Vārds, 21.04.2015., Nr. 16 (868), 10.16. lpp.

6. Rozenbergs J., Briǵis I. Padomju civilprocesuālās tiesības. Rīga: Zvaigzne, 1978.

7. Rosenberg L., Schwab K. H. Zivilprozessrecht. München, 1993, s. 425.

\section{Normativie akti}

8. Administratīvā procesa likums: LV Likums. Latvijas Vēstnesis, 2001. 14. novembris, Nr. 164.

9. Bāriṇtiesu likums: LV Likums. Latvijas Vēstnesis, 2006. 7. jūlijs, Nr. 107.

10. Bērnu tiesību aizsardzības likums. LV Likums. Latvijas Vēstnesis, 1998. 8. jūlijs Nr. 199/200.

11. Civilprocesa likums: LV Likums. Latvijas Vēstnesis, 1998. 3. novembris, Nr. 326/330.

12. Grozījumi Civilprocesa likumā: LV Likums. Latvijas Vēstnesis, 2012. 14. decembris, Nr. 197.

13. Komercnoslēpuma aizsardzības likums: LV Likums. Latvijas Vēstnesis, 2019. 14. marts, Nr. 52.

14. Konkurences likums: LV Likums. Latvijas Vēstnesis, 2001. 23. oktobris, Nr. 151.

15. Par tiesu varu: LV Likums. Latvijas Vēstnesis, Latvijas Republikas Augstākās Padomes un Valdības Ziṇotājs, 1993. 14. janvāris, Nr. 1/2.

16. Recommendation No. $\mathrm{R}(84)$ on the principles of civil procedure designed to improve the functioning of justice, pieejams: https://wcd.coe.int/com [aplūkots 2019. gada 5. maijā]. 


\section{Juridiskā prakse}

17. Par Civilprocesa likuma 441. panta otrās daḷas (ciktāl tā attiecas uz lēmumu par naudas soda uzlikšanu procesuālās sankcijas veidā) atbilstību Latvijas Republikas Satversmes 92. pantam: Satversmes tiesas 2008. gada 5. novembra sprieduma lietā Nr. 2008-04-01. Latvijas Vēstnesis, 2008. 11. novembris, Nr. 175 (3959).

18. Par Civilprocesa likuma 400. panta pirmās daļas 1. punkta un 405. panta pirmās un trešās daļas atbilstibu Latvijas Republikas Satversmes 92. pantam: Satversmes tiesas 2010. gada 17. maija spriedums lietā Nr. 2009-93-01. Latvijas Vēstnesis, 2010. 20. maijs, Nr. 79 (4271).

19. Par Civilprocesa likuma 141. panta pirmās dal̦as, ciktāl tā neparedz tiesības iesniegt blakus sūdzību par lēmumu, ar kuru apmierināts pieteikums par prasības nodrošinājuma atcelšanu, atbilstibu Latvijas Republikas Satversmes 92. pantam: Satversmes tiesas 2012. gada 29. oktobra spriedums lietā Nr. 2012-05-01, Latvijas Vēstnesis, 2012. 31. oktobrī, 172 (4775).

20. Par Civilprocesa likuma $363 .{ }^{20}$ panta piektās daļas (redakcijā, kas bija spēkā līdz 2010. gada 31. oktobrim), ciktāl tā liedz parādniekam pārsūdzēt tiesas lēmumu, ar kuru izbeigts maksātnespējas process, neatbrīvojot parādnieku no atlikušajām parādsaistībām, atbilstību Latvijas Republikas Satversmes 92. panta pirmajam teikumam: Satversmes tiesas 2016. gada 28. septembra spriedums lietā Nr. 2016-01-01. Latvijas Vēstnesis, 2016. 30. septembris, Nr. 190 (5762).

21. Latvijas Republikas Augstākās tiesas Senāta Civillietu departamenta 2006. gada 5. aprīla spriedums lietā Nr. SKC -225.

22. Latvijas Republikas Augstākās tiesas 2007. gada 4. aprīḷa spriedums lietā Nr. SKA-93/2007 (C15075104).

23. Latvijas Republikas Augstākās tiesas Senāta Civillietu departamenta 2012. gada 21. marta spriedums lietā Nr. SKC-98/2012.

24. Latvijas Republikas Augstākās tiesas Civillietu departamenta 2014. gada 28. februāra spriedums lietā SKC-108/2014.

25. Latvijas Republikas Augstākās tiesas 2016. gada 14. aprị̣̄a Rīcības sēdes lēmums lietā Nr. SKA-856/2016 (A420532213).

26. Latvijas Republikas Augstākās tiesas Administratīvo lietu departamenta 2018. gada 9. aprị̣̄a Rīcības sēdes lēmums lietā Nr. A420126016, SKA-772/2018.

\section{Raksti interneta resursos}

27. Braudo S. Définition de Contradictoire. Pieejams: https://www.dictionnaire-juridique.com/ definition/contradictoire.php [aplūkots 09.05.2019.].

28. Kellere K.: Vai sacīkstes princips aizliedz tiesneša iesaistīšanos diskusijā? Pieejams: https:// juristavards.lv/zinas/273224-iii-videolekcija-karena-kellere-vai-bsacikstes-principsb-aizliedztiesnesa-iesaistisanos-diskusija/, sk. Jurista Vārds 20. augusts 2018 [aplūkots 2019. gada 5. maijāā]. 